\title{
Proper recognition: personhood and symbolic capital in contemporary sociology
}

\begin{abstract}
Sociologists maintain an ambivalent relationship to the category of the person, even more so at a time when the category is deemed insufficient for analysis yet appears increasingly significant within the world it purports to capture. This article begins with this ascending significance of the person in the neoliberal world of work, where the personal accumulation of skills and devolution of responsibility to individuals are privileged. Theoretical approaches to personhood attempt to respond to these changed conditions, with the work of Pierre Bourdieu often thought incapable of properly explaining such contemporary phenomena. In response, this article approaches personhood through the frame of Bourdieu's concept of symbolic capital, those properties "misrecognized" as belonging to the person when they are in fact the product of relations in which the person is enmeshed. A reconstruction of the concept in the sociologist's work, along with analyses of its implications for a philosophy of perception and for ideology, will show the way for an unexpected approach both to Bourdieu's own work, reframed through the concept of symbolic capital, and to personhood, which is revealed to be a profoundly and paradoxically relational notion.
\end{abstract}

\section{Keywords}

Bourdieu $\bullet$ personhood $\bullet$ capital $\bullet$ relational sociology 


\section{Introduction}

In sociological thought and inquiry, the person occupies an ambivalent status. On the one hand, sociologists appear to begin from premises hostile to liberal individualism, seeking instead a "communal" regime that effaces the person as a causal power (Gielen, 2005). It is treated by many such researchers as a pre-scientific or theological remain that ought to be extirpated (e.g., Fuchs, 2005; White 1992: 197). On the other hand, while some attempt to integrate the person within their sociological approaches (Donati \& Archer, 20I5; Smith, 20I0), even those wishing to disavow it as an intellectual category have it pressed upon them with greater urgency as contemporary work arrangements demand more attention to the personal. This is the case whether we consider personal "branding" discourses (Vallas and Christin, 20I8), the reflexive cultivation of a labouring self (Farrugia, 20I9), or the accumulation of (human or cultural) "capital" in the person (Skeggs, 20II). At the same time, another current of research suggests that this very model of personhood, in which properties are contained within, is becoming increasingly outmoded in reality, with personal properties coming to be taken less as natural givens and more as products - the outcomes of practice - in an increasingly service-based economy predicated on immaterial labour (Adkins, 2005).

At stake in these opposing positions is the question of the location and mobility of the properties that comprise a person. The traditional liberal, personalist conception locates these properties within individuals who - because they thereby possess them - are ostensibly free to exchange them for a wage. This liberal contract theory vision was famously criticized by Carole Pateman (1988). For Pateman, the employment contract operates according to a fiction: that capacities, labor power, and other properties belonging to an employee can be exchanged for a wage. It is a fiction since these properties are so in name only, not "alienable" or mobile in the sense of the material property for which they are exchanged. Underlying this fiction is a 
more profound one: that persons are fundamentally property owners, equipped first of all with possession of their "own” properties. Pateman (p.I3) here recites "Locke’s famous formulation, 'every Man has a Property in his own Person'; all individuals are owners, everyone owns the property in their capacities and attributes". These capacities, analogous to material objects, can according to this story be exchanged for a wage, since they are "treated as separable from the person" (Pateman, 2002: 33). Implicit in Pateman's critique is an alternative view: that since capacities "are internally related to the person" (I988: I50), to employ the capacities is to exploit the whole person.

As Adkins $(2005 ; 2008)$ points out, capacities deployed in the workplace are acquired over time. While this acquisition is a laborious process, the resulting capacities and properties such as gender, as in her central example - are often taken as intrinsic and natural to the performer (Adkins, 200I: 686). ${ }^{1}$ Despite their natural appearance, Adkins writes, in the "new economy" these properties are subject to external perception and verification. That is, they have importantly become disentangled from the person and depend on an audience or set of customers for verification of their existence. The implication of this claim takes us beyond the sociology of work. Adkins argues that we are potentially witness to "the end of modern notions of personhood", with properties beginning to detach from bodies, spill out, and circulate (2008: I26). Adkins further suggests that sociological approaches, seeking to come to terms with work as it is practiced, nevertheless remain mired in the idealistic view of the person as selfpossessed and capable of owning and accumulating capacities. In particular, Pierre Bourdieu expresses this tradition well, since he - "via notions of property in the person (found, for instance, in the idea that various forms of capital may 'stick' to or be accumulated by the human subject) - always remains trapped within a social contract model of personhood" (2005a: I25). Skeggs (20II) effectively concurs, finding Bourdieu to have mobilized a liberal model of 
personhood, with his recourse to an independent and self-propelling subject interested in accumulating capital, thereby permitting those without these means to fall out of his analytical framework.

These comments on Bourdieu's approach further expose the sociological ambivalence toward the person. The case of Bourdieu indeed magnifies this general ambivalence, since critical interpretations of his work put forth opposite critiques: while he is seen to dissolve the person, rendering it an epiphenomenon of structures (Archer, 2000), he is also depicted as salvaging the actor, but as self-interested and utility-maximizing (Honneth, I995: I87). In light of these divergent treatments, an examination of Bourdieu's approach to the status of the person is broadly instructive for sociology. In the present paper, I hope to provide some support for the place of Bourdieu in a renewed model of personhood, using Adkins' and Skeggs' challenges as points of departure. I will suggest that, contrary to their supposition, reinforced to be sure by Bourdieu's economic terminology of capital and property, attention to the thoroughgoing relational character of the latter's sociological approach entails a more expansive vision of personhood. In particular, I will argue that the person in Bourdieu's work is a relational outcome, the product of interactions taking place "behind" the actor as much as those in which the latter is enmeshed. Central to the everyday production and presence of the person is its dependence on recognition by others, displacing one's "own" properties from within to a space "between" actors.

I will make this argument by a singular focus on the notion of "symbolic capital", a central concept in Bourdieu's work. My argument begins with an exploration of this concept, as it develops from Bourdieu's earliest Kabylia fieldwork, through his elaboration of the notion of field, and up to his late philosophically-engaged work. At its base, symbolic capital refers to 
the status of various forms of capital when they are recognized, or more properly, "misrecognized," as the property of a person rather than the product of the social relations in which these actors are involved (I990b: I39). This suggests already that perception, in the form of "recognition", is a key element, and indeed it is one that preoccupies Bourdieu throughout his career. Thus, I proceed to sketch the outlines of Bourdieu's general approach to perception, its affinity to Gestalt psychology, and the implications this approach has for thinking through classical sociological notions like ideology. The paradoxical character of symbolic capital lies, in fact, in its dependence on perception. That is, properties are only such - they only belong to a person - inasmuch as they are recognized. In the absence of this recognition, the properties effectively evaporate. In this way, symbolic capital remains a thoroughgoing relational notion. In the third part of the article I will pursue its relational dimension to its paradoxical conclusion, addressing how those exercising power are dependent on those subjected to it. Far from the variation on a human capital-accumulating sovereign subject that Bourdieu is sometimes thought to be offering, symbolic capital shows him to posit a fundamentally vulnerable actor: "The fragility of symbolic capital resides in the fact that it is by definition an alienated capital, a capital that necessarily comes from the regard and speech of others" (Bourdieu, 2007: 389). This appears then to be a person whose personhood is externally defined rather than given.

\section{Symbolic capital and the person}

Fundamentally, the symbolic dimension, from which symbolic capital derives, manifests itself in Bourdieu's work as an approach to perception. It operates as an alternative to a "naïve realist" view in which people mechanically react to stimuli in the environment presumed to be present and equally open to all. ${ }^{2}$ In Bourdieu's own words, agents do not react "mechanically to mechanical stimulations, [but] respond to the invitations or threats of a world whose meaning 
they have helped to produce" (Bourdieu, I984: 467). In this respect, he makes clear his debt to Cassirer's philosophical anthropology, which presents the human as an "animal symbolicum" (Cassirer, 1944: 26; see also Wacquant, 2013: 276): "No longer can man confront reality immediately; he cannot see it, as it were, face to face. Physical reality seems to recede in proportion as man's symbolic activity advances" (Cassirer: 25). Bourdieu saw his own advance beyond the neo-Kantianism of Cassirer as consisting in an effort to reconstruct the conditions of production of the apparatus that people deploy to construct the world (Bourdieu, I99Ia). While symbolic construction is indeed undertaken, the symbolic apparatus is neither universal nor randomly distributed. Rather, one inherits a particular manner of constructing and appreciating it. This is, in short, what Bourdieu means by habitus, a historically- and sociallyspecific set of dispositions that permits one to both employ and "decode" the system of symbols that operates between actors and the (social) world.

The crux of symbolic capital lies in this disposition to decode: those disposed to decode a given symbol, and to recognize its "value", produce its value in the very act of recognition. Recognition then becomes an action that "produces what it recognizes" (Bourdieu, I990a: I4I). This renders symbolic capital partly the product of the one who does not possess it. For Steinmetz (2006: 454), this is a Hegelian observation, that "it is not only the dominated but also the dominant" who are dependent on others. This particular observation aligns Bourdieu's approach with certain of Hegel's inheritors who see an unfulfilled search for others' recognition as being a motor for social and/or historical action (see Kojève [1969]). From the other side, Bourdieu reminds his readers of the labour of production "behind" the symbol, so to speak. More specifically, such symbols receive their value as the transfiguration of "baldly objective" material resources (Bourdieu, I990a: I40), either economic resources or physical force. 
Symbolic Exchange in Kabyle Society

Bourdieu's earliest ethnological work in Kabyle villages clarifies this laboured transfiguration and demonstrates how the person becomes implicated as a bearer of value. In dialogue with Lévi-Strauss's reading of Mauss, Bourdieu takes gift exchange as paradigmatic. As LéviStrauss (1987: 47) writes, Mauss erred by taking the isolated instance of gift-giving as his point of departure to explain the circulation of goods. This required him to add a mysterious "hau" quality as the subjective motivation for reciprocation to complete the exchange. Lévi-Strauss instead takes exchange itself as the fundamental phenomenon, rendering isolated instances secondary and automatic, flowing from the structure of exchange. To reach the fundamental phenomenon, the ethnographer must undertake "an objective critique so as to reach the underlying reality" (p.49). For Bourdieu (2000: I89), Lévi-Strauss' reduction effaces the "primary vision", since giving and receiving are not lived as inevitable moments within a circulation, but as discontinuous acts of generosity. A delay between gift and reciprocation, elided in the structuralist approach, is the condition of possibility for the interpretation of the act as one of generosity. The act of giving receives recognition in exchange, a kind of placeholder in situations where material goods are scarce and a delay is necessary before reciprocation. In such conditions it can be said, with Sahlins (I972: 2I3), that "[t]he objective of gathering wealth, indeed, is often that of giving it away". Bourdieu adds that one "also possesses by giving" (Bourdieu, I990a: I26). By rendering indebted those who cannot immediately reciprocate, one maintains something of a "lasting hold", receiving from them affection and admiration. The delay is thus important, since it enables time to "incorporate" the debt. The reception of a gift "turns into internalized gratitude, incorporated recognition, inscribed in the body itself in the form of passion, love, submission, respect, an unrepayable 
and, as people often say, everlasting debt" (Bourdieu, 2000: 198). Owing a debt to the gift-giver places one in a position of subservience to the other person.

The act of giving can be seen to constitute a labour of conversion, an "alchemical" process rendering material resources into perceived symbolic ones concentrated on the person (Bourdieu, 20I6: 2I8). Bourdieu expresses this in terms of the transfiguration and transubstantiation of a power relation into a symbolic relation (I99Ia: I70). Importantly, this transubstantiation requires the exchange to be convincing as gift-giving. So, people labour on the forms of exchange - removing price-tags, tailoring a "thoughtful" gift to the recipient manifest here in care for the manner in which the gift is given. Thus, "what counts is not so much what you give as the way you give it" (1977a: 192). Elsewhere, Bourdieu writes that, "[t]he 'way of giving', the manner, the forms, are what separate a gift from straight exchange, moral obligation from economic obligation" (I990a: I26). The properly personal care devoted to the act of giving, apparent in an expense of time, effort, and goods, seems to suggest for Bourdieu the mechanism by which a material condition can manifest itself in something like the charisma or authority perceived in the person of the giver herself. The particularly personal labour of conversion results in the imputation of a certain quality to that person. This fixing of value in the person becomes especially significant when Bourdieu transfers the model to France: here, a quality is a "being-perceived", a property perceived as "natural" to a person, often in the form of a particular corporeal manner (1977b). Like symbolic capital generally, its specific character remains elusive. Bourdieu attempts to capture it in his early works on the Kabyle, but finds that it is irreducible: "If we can add traits ad infinitum without restoring the totality that intuition immediately grasps, it is because everything here is a matter of manner" (Bourdieu and Sayad, I964: 88). Another attempt at identification results in further 
disappointment, when a property is described as an "indefinable attribute of the man of honor...as fragile and vulnerable as it is imponderable" (Bourdieu, I965: 218).

\section{French Semiotics}

Bourdieu's earliest attempts to conceptualize what becomes symbolic capital in France occurred in the fieldwork conducted in the early I960s in his natal village in Béarn. Here, previously valorised bodily properties - manifest in the peasant manner of being cherished in Kabylia - have suffered a collapse in value. The peasant's manner is associated with the rhythms of agricultural life, and functions as a stigmatized "symbol of economic and social standing" (Bourdieu, 2008: 85). Here, Bourdieu makes use of a far simpler approach than the "transubstantiation" one outlined above. Here, bodies simply express underlying conditions. His earliest attempts to incorporate structuralist semiotics begin to complicate this notion, but the same basic approach applies. In an early sketch of the importance of "lifestyle", Bourdieu (I966a) emphasizes that the symbolic order, though in some sense "autonomous" from the economic order, still expresses the latter. In particular, the symbolic dimensions of social actions

...always express social position following a logic that is the very same as the social structure, that of distinction. Signs... are predisposed by a kind of pre-established harmony to express statutory 'rank', which, as the word suggests, owes the essence of its 'value' to its position in a social structure defined as a system of positions and oppositions. (p.2I6) 
Still, the central importance of "manner" remains, as the consumption of goods is inescapably symbolic. This symbolic logic "transmutes goods into signs, differences of fact into signifying distinctions or, to speak as the linguists do, into 'values', by privileging manner, the form of the action or the object at the expense of its function" (p.2I4). Present here, the metaphor of “transmutation" or, even more significantly, "transfiguration", comes to replace, by Distinction (I984 [1979]), that of "expression", suggesting a growing sensitivity to the multiplicity and autonomy of fields and sub-fields.

Implicit in Bourdieu's mature studies on gift exchange, which begin to appear in 1972 , is a notion that frees us from this idea that symbols merely express something. Accentuating his anthropological side, Bourdieu argues that in differentiated societies "alchemical" processes similar to those of societies without cash take place: just as Malinowski's chief operates as a "tribal banker", unilaterally bestowing goods that reap loyalty and respect, so do wealthy individuals donate to foundations and cultural institutions to justify their positions (Bourdieu, I977a: 196). Above all, the accumulation of symbolic capital operates in such societies by the transubstantiation of material wealth into "lifestyle", into goods that attest to "the taste and distinction of their owner" (p.I97). Lifestyle is, crucially, anchored in the person; it appears "natural" through "misrecognition" of its origin. Here, seemingly wasteful expenditures on luxury goods and gratuitous bodily exercises are instances of the conversion of economic force into valorised signs, into symbolic capital imputed to the person.

Symbolic Capital and the Origin of "Field"

Through Bourdieu's early focus on personal manner and form, we are afforded a novel way to identify the origins of his field concept, which initially appears hostile to the person as an 
explanator factor. In fact, the same labour of transfiguration is present here in the form of capital conversion. This process transforms generic and "objective" capitals like economic and cultural capital into specific capitals recognizable within particular spaces. While, as Steinmetz (20I6: II7) notes, Bourdieu initiated his field theory by entering the debate about the weight of internal and external causal factors in the production of cultural goods, the notion undergoes a great many revisions. I would like to concentrate on one of its earliest revisions, which implicates the study of religion (Bourdieu, I990b: 22). It enables us to understand how a reflection on form, an attempt to grasp the relative autonomy of cultural products (20I3: I3), brings us to the final resting place of symbolic capital: a means to grasp the accumulation of "reasons for being".

These elements are integrated by a qualified appropriation of a large number of philosophical and anthropological traditions. In his "On symbolic power," Bourdieu (I99Ia) seeks to clarify the symbolic dimension, synthesizing what he sees as unnecessarily partitioned approaches: the neo-Kantian tradition that conceives of symbols as means of constructing the world is melded with the structuralist tradition that conceives them as tools of communication. The two of these are most significantly combined with the Marxian and Weberian approaches concerned with political and ideological functions of symbols. Through this synthesis, Bourdieu asserts that the dominant wield force by the very symbols that all agents use to construct the social world and to communicate (I99Ib: I67). This assertion owes much in particular to Weber and Marx, both of whom concentrated on the establishment of a class of agents - in the first instance, priests - specializing in the production of specifically symbolic goods. It follows that a space emerges in which representatives - persons on whom a group bestows credit - vie over the symbolic power to represent the world in a particular way (I99Ia: I82). 
Combining elements of Marx and Weber's writings, Bourdieu (I99Ib) offers a historical sketch of the emergence of the propensity to struggle over the power to administer symbolic goods and thus to impose a particular representation of the world. Its origin is located in the emergence of the "religious field". Bourdieu asserts both that a properly religious field arises with the development of the town in opposition to the country and that as this occurs a division between physical and intellectual labour emerges. This latter division enables the mind to intend something other than existing practice: "from now on, consciousness is in a position to emancipate itself from the world and to proceed to the formation of 'pure' theory, theology, philosophy, morality, etc.” (Marx and Engels, I977: 52). Bourdieu proceeds to argue, following Weber, that in the towns, with the development of rationalized "occupational activities relatively independent of natural risks" (Bourdieu, I99Ib: 6), transcendental forces begin to be conceived as intellectual and existential problems. Those seeking explanation - or, better yet, justification - of their existence turn to a corps of specialists, who have established themselves as administrators of the goods of salvation. These specialists, institutionalized in the clergy, furnish symbolic goods to those laypeople who recognize them, offering to the latter legitimacy in the form of a theodicy of their own "good fortune" (Weber, 2004: 60).

Symbolic capital - as credibility and legitimacy - connects to the religious field in two ways. First, priests and prophets struggle over a specific kind of symbolic capital or credit, obtained by attracting a following among laypeople. These struggles have a strictly religious focus, concerned with such matters as doctrine interpretation, but nevertheless concern laypeople insofar as they represent the latter. Their specific "symbolic interests - not losing face, not losing your constituency, shutting up your opponent... etc. - are such that, by serving them and obeying them, it often happens that agents serve their mandators" (Bourdieu, I99Ia: 215). The second way symbolic capital operates here concerns these mandators, the laypeople: the 
symbolic "products" (messages and rituals) furnished by the specialists within the religious field function to transform laypersons' otherwise arbitrary "fortune", that is their objective position, into a legitimate position. They thus obtain symbolic capital by means of a mediating "religious labour", enacted by a group of actors who specialize in the manipulation of symbols and who thereby transmute material goods into symbolic ones that are, once again, borne by the person. What these specialists offer to the laity are "justifications for existing in a determinate social position and existing as they exist" (I99Ib: I6).

\section{The State as Guarantor}

If the religious field once offered justifications for existence, reasons for being, in the form of symbolic goods, Bourdieu is quite clear that this is no longer the case: "[w]hat is expected of God is only ever obtained from society" (Bourdieu, I990b: 196) and, in particular, from the state, which functions as an absolute judge, reconciling conflicting evaluations and pronouncing its verdict on all. By defining somebody, imposing a collective representation, the state produces what it declares, in the manner of the performative statement. It achieves this through even the most routine bureaucratic actions:

[A]cts of nomination, from the most trivial acts of bureaucracy, like the issuing of an identity card, or a sickness or disablement certificate, to the most solemn, which consecrate nobilities, lead, in a kind of infinite regress, to that realization of God on earth, the State, which guarantees, in the last resort, the infinite series of acts of authority certifying by delegation the validity of the certificates of legitimate existence (Bourdieu, 2000: 245) 
Bourdieu's most sustained exploration of this nomination process appears in The State Nobility (1996), in which he suggests an analogy between noble and academic titles. Each, in its respective period, secures access to scarce positions by the nomination of a central figure, whether the king, who "distribute[s] symbolic capital in the form of offices and honors" (I998: 50), or the state, which accomplishes it primarily by awarding academic titles. Bourdieu adds that such a nomination is an act of "state magic", which institutes a "sacred" group of "elected" figures (1996: I03), henceforth separated from the profane masses. For these elect, the academic title is something of "a genuine ontological promotion, a transmutation, a change of nature or essence" (p.376). The school, then, certified by the state, distributes symbolic goods in a manner analogous to the religious field, certifying those fortunate enough to "pass", granting legitimacy in the form of the qualification. This form of legitimacy is crucially centred on a combination of natural "gifts", merit, and competence, all forms that are attributed to the person (p.266). The rite of passage not only aims to have others recognize the superiority of the nominated but to have the nominated come to perceive herself as such. The institution accomplishes this, Bourdieu argues, by exploiting "the power to act upon bodies through the symbolic efficacy of signs" (p.II8).

This exploration and elaboration of the concept of symbolic capital across Bourdieu's oeuvre shows in a pronounced fashion a vacillation between the person (notions like honor and charisma) and impersonal structures (like the field and the state). Yet he attempts to incorporate into his approach the powerful everyday belief in, and action upon, the person. This is seen most clearly in his discussion of the state's "rite of institution", which, "despite its apparent impersonality...is always highly personal" (2000: 243), requiring the person's assumption of its demands, thereby durable transforming her by acting on her perceptions of herself and others' perceptions of her (20I5: I75). 


\section{Bourdieu's phenomenology of perception}

In this account of symbolic capital, it is clear that perception - and specifically the perception of persons' bodies - is at the concept's core. Bourdieu's scattered comments on perception, it understandably follows, are concerned primarily with persons' bodies. In an early sketch on the body, this tight relationship between the social definition of the person and perception is apparent:

The body, as a perceptible form, "produces", we say, "an impression" (what ordinary language calls the physique, or physical appearance-where the properly physical conformation of the body and the manner of carrying which expresses it converge), and is, of all the manifestations of the "person", the one that is less and less easily modifiable, temporarily and above all definitively, and, at the same time, the one that is held to most adequately signify (because it is outside of all signifying intention) the "profound being", the "nature" of the "person". (Bourdieu, I977b: 5I)

As I suggested in my discussion of "lifestyle" above, bodies constitute the point at which objective forms of capital become recognizable, become "symbolic". Lifestyles are particularly important in Bourdieu's discussion of symbolic capital, for they amount to "sign systems that are socially qualified (as 'distinguished', 'vulgar', etc.)" (Bourdieu, I984: I72). Mediated by the body, lifestyles operate "an alchemy which transforms the distribution of capital, the balance-sheet of a power relation, into a system of perceived differences, distinctive properties" (p.I72). The key terms are contained therein: difference and perception. While difference is clearly present in the structuralist approach that Bourdieu appropriated, he adopts from Gestalt 
theory a cognate perceptual theory: "Perception is basically diacritical, it distinguishes 'figure' from 'background"” (I990b: 79). This is especially pertinent in relation to symbolic capital, for as Bourdieu says elsewhere: "the logic of the symbolic is almost automatically dualist" (2015: I32). In this section, I would like briefly to examine Bourdieu's approach to perception, and in particular outline his debt to ideas from Gestalt psychology as mediated by the work of Maurice Merleau-Ponty.

My point of departure is Bourdieu's (2015: 285) stated motivation to construct a science of a properly practical logic, that does not reduce it to a debased form of rational logic. This amounts, Bourdieu states, to an attempt to "establish the possibility of a science of the obscure and confused which is itself neither obscure nor confused" (Bourdieu 20I5: 285), a project that Bourdieu saw as analogous to that of Merleau-Ponty. For Bourdieu, Merleau-Ponty strove "to constitute perception as a form of knowledge that is not simply a degraded form of scientific knowledge" (p. 285). In addition to his numerous references to Merleau-Ponty, Bourdieu (in Sapiro, 2004: 84-85) states that his The structure of behavior (1963) in particular figures as a crucial point of reference and source of inspiration. In this work, Merleau-Ponty undertakes a Gestalt-inspired critique of behaviourist thought within psychology, mobilizing the work of neurologist Kurt Goldstein. Merleau-Ponty's critique takes as given the Gestalt principle of the irreducibility of perceptual forms: elemental stimuli do not form sensations that are subsequently categorized and classified in the visual cortex, as if perception merely provided stimuli for higher cognitive judgment. Rather, the meaning of the world is already there, evident and given. Bourdieu (I99Ia: 237) verges on this position when he writes that "perceptual configurations, social Gestalten, exist objectively". Still, it is necessary to recall that these configurations exist "objectively" only insofar as there exist agents disposed to 
perceive them. This is the case for the Gestalt theorists too: forms objectively exist, but only for those organisms whose perceptual systems are constructed in accordance with them.

The crux of the matter rests in this last clause - that the meaning of the world is given to those disposed to perceive it. As Martin (20II: 225) points out, Gestalt theory affirms the "veridical nature of our perceptual system", suggesting that organisms are not fundamentally deluded about the world but are attuned to its regularities, owing particularly to a relation of "consubstantiality", in which they have co-evolved with this world. Still, he argues, such an approach, which assumes "that evolution gave all people a single set of eyes" (p.260), does not resolve the problem of the variability of qualities that experientially inhere in objects. That is, how can we explain a certain food being distasteful or a certain organization being disagreeable to one and not to another? What is needed, Martin suggests, is recognition of the role of habit, experiences deposited within the organism as the latter has developed. Thus, the Gestalt evolutionist approach still applies, with the caveat that humans develop in different ways according to different social and cultural conditions.

We should take from this detour through Gestalt theory the idea that forms are not imposed upon indifferent stimuli but are fundamentally constitutive of the perception: "The 'form,' on this view, would be present in sense-knowledge itself, and the incoherent 'sensations' of traditional psychology would be a gratuitous hypothesis" (Merleau-Ponty, I992: 74). So, when Bourdieu speaks of the form that power takes when it is converted into symbolic capital, that is, when it is legitimate, this is not to say that a bald power hides behind its symbolic form. Rather, this is power as it has been wrought by a laborious transfiguration. This is most acute when we consider the bodies of persons, whose "charisma" is felt in interpersonal encounters or the objects they produce (Bourdieu, I984: 208). 


\section{Relational personhood}

Bourdieu's focus on perception inescapably points to a perceiver, who is paradoxically endowed with the power to recognize — to imbue the person of the other with power or capital. Here we come a long way from the liberal contract approach from which we began, with Pateman's critique. Recall that this position endows people with properties held within their persons, while the Bourdieusian approach places these properties in some indeterminate location. On the one hand, they are the product of the gaze of the other. This renders these properties particularly "alienated" and fragile, subject for their very existence on the judgment of others. On the other hand, however, they are not merely the product of the other's gaze, which would amount to a kind of idealism, reducing the social world to a play of appearances. Rather, following the Gestalt principles outlined above, the observer's perceptions are responding to something, and can be described as "well-founded" or veridical. How, then, can these properties that constitute the person be dependent on others' recognition and have some material foundation? The answer to this question requires us to deepen our engagement with Bourdieu's relational principles, pointing to another way of making sense of the new forms of personhood that Adkins identified above.

From a relational perspective, subject's ostensible sovereign status is belied by her dependence on those who recognize her. So it makes little sense to include Bourdieu's agent among the actors of liberal contract theory, who accumulate skills and capabilities in the form of cultural capital that remain "within". Rather, Bourdieu's agent is fundamentally vulnerable. Dependent for its power, for the value of its accumulated properties, on the regard of others, what the Bourdieusian agent possesses seems to remain "between" it and those others. In his Pascalian meditations, Bourdieu (2000) elaborates upon this notion, depicting the social agent's "being" 
as "a being-perceived, condemned to be defined as it 'really' is by the perception of others" (p.I66). The properties that comprise one's "person", then, are not only not pre-social, as the liberal conception might have it, but are relational, the product of interaction with others in an “encompassing system" (Steinmetz, 2006: 455). Crucially, this appropriates a theme of Pascal (2005), in which the philosopher, whose aegis Bourdieu takes up (Wacquant, 20I0), seeks to understand the properties that define a powerful figure such as a king. Pascal here anticipates a Weberian approach to legitimacy, to which Bourdieu is likewise indebted (Swartz, 2013: 80), and whose principle is expressed in the phrase, "force cannot assert itself as such" (Bourdieu, 2000: I04; I998: 53). Rather, it is produced through and mediated by recognized symbols. One of Pascal's most notable "pensées" illustrates this:

$[\mathrm{T}]$ he custom of seeing kings accompanied by guards, drums, officers, and all the things that direct the machine to yield respect and fear, makes their faces, when they are sometimes seen alone without these trappings, impress respect and fear in their subjects, because we cannot separate in thought their persons from what usually accompanies them. And the world, which does not know that this effect is the result of custom, believes that it derives from a natural force. From this come words: the character of divinity is stamped on his face, etc.” (Pascal, 2005: S59/L25)

A potential, but ultimately too superficial, reading of this event would be that it is a simple mistaking of the form a person takes (a king with its associated "trappings") for some material substrate (the person himself). This interpretation implies that a substance persists beneath a form, and that the form enveloping the substance comes to be mistaken for the substance itself. This obvious critique, which identifies the most superficial of contradictions, Pascal associates with the "demi-habile", the "half-learned" thinker, who delights in pointing out the 
contradictions of "the people" (Bourdieu, 2000: I89). For Bourdieu (2015: I70), these "naïve theories of ideology" posit that "it suffices to disrobe the judge of his ermine and toga" to dispossess him of his power. This approach ignores the conditions that encourage the false belief and rests on a faulty theory of perception, neglecting that "the ermine and toga are power realized". Drawing on the Gestalt theory of perception, we can say that the king is not a mere datum, passively perceived and subsequently classified as "powerful king", but inescapably presents as a king, particularly because the perceiver maintains a specific relation (of subordination) to him. As Pascal (Si23/L89) points out, "they do not want me to honor a man clothed in brocade and followed by seven or eight lackeys. Why, he will have me thrashed if I do not salute him". The hierarchical relation that the subject maintains with the king obliges the former to perceive the king as a king. As Bourdieu (2015: 170) puts it, recalling this pensée, “it's imaginary, but, at the same time, it's entirely real, and if you transgress, you'll be beaten".

Elaborating the Pascalian approach, Marin (1988) assigns to symbols (like clothing) a central role in constituting the power of the dominant. Marin writes that, owing to appearance, those who assume the king or nobleman to be essentially superior produce, in a certain respect, the truth of his essential superiority. By yielding to him as if he were truly great, they render him such. The noble, it follows, "believes that his own being is somehow superior to that of others" (Marin, 1979: 247). This assumption suggests for Marin that the relation "is translated into an ontological identity.... [T]he nobleman's being results from the interiorization of a relationship" (p.248). Again, we could confine this to a labour of production on the part of the perceiving subject, whose acknowledgement "produces what it recognizes" (Bourdieu, I990a: I4I). At the same time, however, their well-founded recognition is only possible because of labour undertaken "backstage", as it were. The signs, which the noble's subordinates recognize, are similarly the product of the labour of innumerable others - the officers surrounding him, 
his lackeys, and especially those who tend to his appearance. As Pascal (Si30/L96) writes, "[t]o be elegant is not mere vanity, for it shows that a great number of people work for you... The more hands you have, the more powerful you are". Marin implies that the noble's appearance stores power: the many "hands" that work for him, the force at his disposal, veritably transform his body as they realize themselves as signs. This is, once again, no "mere" surface or appearance, for it results in the body's "real multiplication and augmentation" (Marin, I988: 27), similar to the harnessing of "social energy" which Bourdieu (I986) describes as being at the centre of the appropriation of capital. Marin continues:

The clothes, the lace, the ribbons, the wig and its curls are not an addition, supplement, ornament, or decoration of the body. It is the body that is multiplied, the organic 'instrument' [suppôt] that, passing into the architecture of the signs that cover it, acquires through it an ordered, instituted, and legitimated plurality, a power (1988: 2728).

Owing to the multitude of signs and the "hands" working to produce them, the person extends further as it encompasses a set of material artefacts. The proliferation of portraits, medals and coins emblazoned with the king's likeness, as well as narrative accounts of his monumental deeds, function like a "real presence" (Bourdieu and Derrida, 1992: 3), extending the body of the king beyond the bounds of his "person" to produce deference and respect even in the king's absence.

Crucially, the paradigm of the king, as Marin casts it, demonstrates the pliability of the person's bounds. If the person of the king is extended, it potentially suffuses subjects' lifeworlds, resulting in the expression of a person's authority in the absence of a command, "wielded 
without having to be wielded" (Bourdieu, 20I3: 298). This is precisely symbolic violence, as Bourdieu describes it. Authority is exercised by mechanisms like self-selection, mediated by the perceptual world: it can be "sedimented" "in things (scepters and crowns, ermines and gowns in another time, luxury cars and lavish offices nowadays)" (p.298). Such objects - vague extensions of the person - have an "affordance character" that functions, in effect, as a command that need not be uttered. The phenomenal world thereby furnishes imperatives, "inscribed like a watermark in the situation, as objective potentialities, urgencies" (2000: I43). Personhood here expands as far as its power is recognized, with the boundaries of the person becoming labile, delimited by others' recognition.

\section{Conclusion}

Far from resolving sociology's ambivalent attitude to personhood, Bourdieu's approach affirms it, making for a situation in which "the social conditions of the production of the person" manifest themselves in the "internalization" of the social (Bourdieu, 2015: 333). Here, personhood is defined not intrinsically but relationally, with the person comprising the world. Because relations vary, so too do persons. In the sketch of symbolic capital above, we saw the wide array of cultural and historical sites to which the concept has been applied, rendering the same concept potentially applicable in the face of great variation. In our case, it permits both the identification of properties within the person, as the liberal notion decrees, and the kind of phenomena Adkins (2008) suggests are increasingly common, in which personhood is verified by an external perceiver attributing properties to the person. While this historical versatility accounting for personhood at the height of industrial capitalism as well as in the "new economy" - has its obvious benefits, its capaciousness has raised questions concerning the "ambiguity about when his analytic concepts were meant to be universal, general to modernity or states or capitalism, or specific to a particular context" (Calhoun, 20I3: 36). At the least, 
however, we should take seriously Bourdieu's stated aim to uncover constants and invariants and recognize that these concepts are neither intended to treat only specific contexts nor expected to be simple reflections of them.

I began this article by noting that Bourdieu is commonly taken to offer a vision not too dissimilar to that of human capital theorists. The crucial distinction between the two, I suggest, returns us to Bourdieu's relationality: properties comprising the person are only so insofar as they are recognized as such. This has the corollary that personhood extends beyond what we ordinarily understand it to be; now, properties persist in some respect between people disposed to possess them and others disposed to attribute these possessions to their "rightful" owners. Here we encounter the dilemma faced by the dominated, who are the producers, by acts of recognition, of the very power that binds them. It follows that accounting for social or historical change demands attentions to the perceptual, symbolic political efforts aimed at transforming the principles of the "vision and division of the social world" as much as those objective conditions that make certain perceptual principles more or less likely (see Wacquant [20I3]). The overbearing power of the dominant should not prevent us from recalling that symbolic capital remains a fragile, alienated capital (Bourdieu, 2007).

\section{References}

Adkins, L. (200I) Cultural feminization: “money, sex and power” for women. Signs 26 (3): 669-695.

Adkins, L. (2005) The new economy, property and personhood. Theory, Culture \& Society, 22(I), pp.III-I3O.

Adkins, L. (2008) From retroactivation to futurity: the end of the sexual contract? NORANordic Journal of Feminist and Gender Research, I6(3), pp.I82-20I. 
Archer, M.S. (2000) Being human: the problem of agency. Cambridge: Cambridge University Press.

Bourdieu P. (1965) The sentiment of honour in Kabyle society. In: Perestiany JG (ed) Honour and shame: the values of Meditteranean society. London: Weidenfeld and Nicholsons, I9I-24I.

Bourdieu P. (1966a) Condition de classe et position de classe. Archives Européen de Sociologie 7: 20I-229.

Bourdieu P. (1977a) Outline of a theory of practice, Cambridge: Cambridge University Press.

Bourdieu P. (I977b) Remarques provisoires sur la perception sociale du corps. Actes de la recherche en sciences sociales I4: 5I-54.

Bourdieu P. (1984) Distinction: a social critique of the judgement of taste, Cambridge, MA: Harvard University Press.

Bourdieu, P. (1986) The forms of capital. In: J. Richardson (Ed.) Handbook of Theory and Research for the Sociology of Education. New York: Greenwood, 24I-258.

Bourdieu P. (I990a) The logic of practice, Cambridge: Polity Press.

Bourdieu P. (I990b) In other words: essays towards a reflexive sociology, Stanford, CA: Stanford University Press.

Bourdieu P. (I99Ia) Language and symbolic power, Cambridge: Polity Press.

Bourdieu P. (I99Ib) Genesis and structure of the religious field. Comparative Social Research I3: I-44.

Bourdieu P. (1996) The state nobility: elite schools in the field of power, Cambridge, UK: Polity Press.

Bourdieu P. (1998) Practical reason: on the theory of action, Cambridge: Polity. Bourdieu P. (1999) Scattered remarks. European Journal of Social Theory 2: 334-340.

Bourdieu P. (2000) Pascalian Meditations, Stanford: Stanford University Press. 
Bourdieu P. (2007) La noblesse: capital social et capital symbolique. In: Lancien D and Saint-Martin M (eds) Anciennes et nouvelles aristocraties de I880 à nos jours. Paris: Editions de la MSH, 385-397.

Bourdieu P. (2008) The bachelors' ball: the crisis of peasant society in Béarn, Cambridge: Polity.

Bourdieu P. (20I3) Séminaires sur le concept de champ, I972-I975. Actes de la recherche en sciences sociales 200: 4-37.

Bourdieu P. (2015) Sociologie générale: cours au Collège de France (I98I-1983), Paris: Seuil.

Bourdieu P. (20I6) Sociologie générale: cours au Collège de France (I983-1986), Paris: Seuil.

Bourdieu P and Sayad A. (I964) Le déracinement : la crise de l'agriculture traditionnelle en Algerie, Paris: Editions de Minuit.

Bourdieu P and Derrida J. (I992) Pour Louis Marin. Liber: Revue européenne des livres I2: 34.

Calhoun, C. (20I3) For the social history of the present: Bourdieu as historical sociologist In: Gorski P (ed) Bourdieu and historical analysis. Durham: Duke University Press: 3666.

Cassirer E. (1944) An essay on man: an introduction to the philosophy of human culture, New Haven: Yale university press.

Donati P and Archer MS. (20I5) The relational subject, Cambridge, UK: Cambridge University Press.

Farrugia, D. (2019) The formation of young workers: The cultivation of the self as a subject of value to the contemporary labour force. Current Sociology, 67 (I), pp.47-63. 
Fuchs, C. (200I). Against essentialism: a theory of culture and society. Cambridge, MA: Cambridge University Press.

Gielen, P. (2005). Art and social value regimes. Current Sociology, 53 (5), pp.789-806.

Honneth A. (1995) The fragmented world of the Social: essays in social and political philosophy. Albany: SUNY Press.

Kojève, A. (1969) Introduction to the reading of Hegel. New York: Basic Books.

Lévi-Strauss C. (1987) Introduction to the work of Marcel Mauss, London: Routledge \& Kegan Paul.

Marin L. (1979) On the Interpretation of Ordinary Language: A Parable of Pascal. In: Harari J (ed) Textual Strategies: Perspectives in Post-Structuralist Criticism. Ithaca, NY: Cornell University Press, 239-259.

Marin L. (1988) Portrait of the king, Minneapolis: University of Minnesota Press.

Martin JL. (20II) The explanation of social action, New York: Oxford University Press.

Marx K and Engels F. (1977) The German Ideology: part one, London: Lawrence \& Wishart. Merleau-Ponty M. (1963) The structure of behavior, Boston: Beacon Press.

Merleau-Ponty M. (1992) Texts and dialogues, Atlantic Highlands, NJ: Humanities Press.

Pateman, C. (1988) The sexual contract. Cambridge: Polity.

Pateman, C. (2002) Self-ownership and property in the person: Democratization and a tale of two concepts. Journal of Political Philosophy, Io (I), pp.20-53.

Pascal B. (2005) Pensées, Indianapolis, IN: Hackett Publishing Company.

Sahlins M. (1972) Stone Age Economics, Chicago: Aldine-Atherton.

Sapiro G. (2004) Annexe : entretien de Pierre Bourdieu avec Gisèle Sapiro In: Pinto L, Sapiro G and Champagne P (eds) Pierre Bourdieu, sociologue. Paris: Fayard, 79-92.

Skeggs, B. (20II). Imagining personhood differently: Person value and autonomist workingclass value practices. The Sociological Review, 59(3), pp.496-5I3. 
Smith, C. (20I0) What is a person? Rethinking humanity, social life, and the moral good from the person up. Chicago: University of Chicago Press.

Steinmetz, G. (2006) Bourdieu's Disavowal of Lacan: Psychoanalytic Theory and the Concepts of "Habitus" and "Symbolic Capital". Constellations, I3: 445-464.

Steinmetz G. (20I6) Social fields, subfields and social spaces at the scale of empires: explaining the colonial state and colonial sociology. The Sociological Review Monographs 64: 98-I23.

Swartz, D.L. (2013) Symbolic power, politics, and intellectuals: the political sociology of Pierre Bourdieu. Chicago: The University of Chicago Press.

Vallas, S.P. and Christin, A. (20I8) Work and identity in an era of precarious employment: how workers respond to "personal branding" discourse. Work and Occupations, 45 (I), pp.3-37.

Vandenberghe, F. (I999) “The real is relational”: an epistemological analysis of Pierre Bourdieu's generative structuralism. Sociological Theory, I7: 32-67.

Wacquant LJD (20I0) Pascal et la sociologie, Philosophie Magazine, 37: 75.

Wacquant LJD. (20I3) Symbolic power and group-making: On Pierre Bourdieu's reframing of class. Journal of Classical Sociology I3: 274-29I.

Weber M. (2004) Introduction to the Economic Ethics of World Religions. In: Whimster S (ed) The essential Weber: a reader. London: Routledge, 55-80.

White H.C. (1992) Identity and control: a structural theory of social action. Princeton: Princeton University Press.

\footnotetext{
${ }^{1}$ Adkins' claim here is more complex, since gender asymmetry operates. Consistent with the notion of emotional labour, she writes that for women "feminine" practices tend to be
} 
naturalised (and therefore unrewarded), while for men they are perceived in a valorised fashion as the product of a performance.

${ }^{2}$ The "naïve realism" of the empiricist, to whom Bourdieu opposes himself, is not that of the realist tradition associated with somebody like Roy Bhaskar, who begins from similar antipositivist premises and is somebody with whom Bourdieu appears to have expressed some affinity (see remarks in Vandenberghe [1999: 62]). 


\section{University Library}

\section{- M M I N E R VA A gateway to Melbourne's research publications}

Minerva Access is the Institutional Repository of The University of Melbourne

Author/s:

Mead, G

Title:

Proper recognition: Personhood and symbolic capital in contemporary sociology

Date:

2020-06-27

Citation:

Mead, G. (2020). Proper recognition: Personhood and symbolic capital in contemporary sociology. CURRENT SOCIOLOGY, 69 (1), https://doi.org/10.1177/0011392120932943.

Persistent Link:

http://hdl.handle.net/11343/258484 